\title{
Developmentally Regulated Expression of a Truncated Myosin Light-Chain $1_{\mathrm{F}} / 3_{\mathrm{F}}$ Gene
}

\author{
LEONARD I. GARFINKEL ${ }^{* *}$ AND NORMAN DAVIDSON \\ Division of Chemistry, California Institute of Technology, Pasadena, California 91125
}

Received 9 March 1987/Accepted 23 July 1987

\begin{abstract}
Fast skeletal muscle myosin light-chain 1 (MLC1 $\left.1_{f}\right)$ and myosin light-chain 3 (MLC3 (MRNAs $_{\text {f }}$ are both derived from a single rat $M L C 1_{\mathrm{f}} / 3_{\mathrm{f}}$ gene. $M L C 1_{\mathrm{f}}$ mRNA begins at the first exon of the gene, while $\mathrm{MLC3}_{\mathrm{f}}$ mRNA begins with exon 2, 10 kilobases downstream. Both mRNAs require alternate splicing of internal exons for accurate expression. We showed that a truncated rat $M L C 1 / 3_{f}$ gene lacking exon 1 and the first 6.3 kilobases of the intron separating exons 1 and 2 produced rat $M L C 3_{f}$ mRNA in a developmentally regulated manner after introduction into myogenic mouse cells, thus demonstrating in vivo the presence of a functional promoter associated with exon 2 . Correctly spliced mRNA was produced after transfer of this truncated gene into both myogenic and nonmyogenic cells, indicating that the pattern of splicing of this complex transcript was due to a structural feature of the RNA and was independent of cell type.
\end{abstract}

Myosin light chains 1 and $3\left(\mathrm{MLC1}_{\mathrm{f}}\right.$ and $\mathrm{MLC} 3_{\mathrm{f}}$, respectively) are members of the family of contractile proteins whose expression is coordinately regulated with the onset of muscle differentiation. Both proteins are encoded by a single gene (Fig. 1) with a complex pattern of expression (7-9). The rat $M L C 1_{\mathrm{f}} / 3_{\mathrm{f}}$ gene (8) spans 22 kilobases $(\mathrm{kb})$ of DNA and contains nine exons (Fig. 1A). In fast muscle tissue the gene yields two different mRNAs, those for $\mathrm{MLC1}_{\mathrm{f}}$ and $\mathrm{MLC}_{\mathrm{f}}$. $M C L 1_{\mathrm{f}}$ mRNA contains exon 1 , exon 4 , and exons 5 through 9. $M L C 3_{f}$ mRNA contains exon 2 , exon 3 , and exons 5 through 9 (see Fig. 2B). Thus, the two mRNAs differ completely in their first two exons yet are identical in their last five exons. Accordingly, the protein products of these mRNAs, MLC $1_{f}$ and $M L C 3_{f}$, differ in sequence at their amino termini and are identical at their carboxy termini.

The existence of functional promoters for both $\mathrm{MLCl}_{\mathrm{f}}$ and $\mathrm{MLC}_{\mathrm{f}}$ mRNAs has been demonstrated by in vitro studies (13), suggesting that differential promotion is the primary means of generating the two different mRNAs. We wished to determine whether $\mathrm{MLC}_{\mathrm{f}}$ mRNA synthesis in vivo is mediated via its own promoter and if so, whether this promoter can be regulated independently of the $\mathrm{MLC1}_{\mathrm{f}}$ promoter and flanking sequences distal to the $\mathrm{MLCl}_{\mathrm{f}}$ promoter.

Two overlapping genomic clones in $\lambda$ Charon 4a (Fig. 1B) were used in the construction of pMLC19.7 in pUC-18. Clone pMLC19.7 contains the entire 10.6-kb MLC3 $_{\mathrm{f}^{-}}$ encoding region of the gene plus $3.3 \mathrm{~kb}$ of sequence upstream of the $\mathrm{MLC} 3_{\mathrm{f}}$ promoter and $5.8 \mathrm{~kb}$ of $3^{\prime}$-flanking sequence (Fig. $1 \mathrm{C}$ ). It does not contain the $\mathrm{MLC1}_{\mathrm{f}}$ promoter or the first $6.3 \mathrm{~kb}$ of the large intron separating the $\mathrm{MLCl}_{\mathrm{f}}$ promoter from the $\mathrm{MLC}_{\mathrm{f}}$ promoter. To determine whether this incomplete gene contains the information essential for regulated expression of the $M L C 3_{\mathrm{f}}$ mRNA after gene transfer into heterologous myogenic cells, we introduced pMLC19.7 into mouse myogenic cell lines $\mathrm{C}_{2} \mathrm{C}_{12}(16)$ and $\mathrm{BC}_{3} \mathrm{H} 1$ (12) by DNA-mediated cell transformation (15). The plasmid DNA used in the transformations was either intact or linearized by digestion with $B a m H I$, which cuts pMLC19.7 once at the vector-insert boundary. Cells were

\footnotetext{
* Corresponding author.

† Present address: Department of Membrane Research, Weizmann Institute of Science, Rehovot, Israel.
}

cotransformed with pNEO3 (3), which confers resistance to the neomycin analog G418. Pools of G418-resistant clones were used to minimize the contribution of position effects $(5$, $6,14)$ to the results. The intact plasmid resulted in a higher DNA copy number than did the linearized plasmid (about 25 copies per haploid genome versus 5 copies per haploid genome) in both $\mathrm{C}_{2} \mathrm{C}_{12}$ and $\mathrm{BC}_{3} \mathrm{H} 1$ transformants (data not shown). $\mathrm{C}_{2} \mathrm{C}_{12}$ cells transformed with intact or BamHIdigested pMLC19.7 are designated $\mathrm{C}_{2} \mathrm{C}_{12} / 19.7$ and $\mathrm{C}_{2} \mathrm{C}_{12} / 19.7 \mathrm{~B}$, respectively. Transformed $\mathrm{BC}_{3} \mathrm{H} 1$ cells are similarly designated $\mathrm{BC}_{3} \mathrm{H} 1 / 19.7$ and $\mathrm{BC}_{3} \mathrm{H} 1 / 19.7 \mathrm{~B}$.

RNAs from undifferentiated and differentiated cells of transformed cell lines were isolated and subjected to nuclease $\mathrm{S} 1$ analysis. The pXA-1 cDNA probe, derived from an MLC $1 / 3$ cDNA clone (1), begins in exon 5 and ends in exon 9 (Fig. 2B). The signal obtained with this probe in rat tissue reflected the presence of both $M L C 1_{f}$ and $M L C 3_{f}$ mRNAs, since the cDNA included sequences which they have in common. However, in the transformants, any signal corresponding to rat myosin light-chain mRNA must have been entirely derived from $M L C 3_{f}$ because of the absence of the $\mathrm{MLC1}_{\mathrm{f}}$ promoter and exon 1 in pMLC19.7. A total of 417 bases of the 1,058-base probe should have been protected from digestion by nuclease $S 1$ after hybridization to rat RNA. Although mouse $\mathrm{MLC1}_{\mathrm{f}}$ and $\mathrm{MLC}_{\mathrm{f}} \mathrm{mRNAs}$ are highly homologous to those of rats $(1,9)$, exon 9 of the rat gene contains a sequence of 8 bases which is absent from the mouse gene (Fig. 2B). This resulted in a nuclease S1sensitive loop of 8 bases when the probe was hybridized to mouse mRNA, resulting in a protected product of only 340 bases (Fig. 2B). The nuclease $\mathrm{S} 1$ products from rat and mouse myosin light-chain mRNAs could thus be resolved (Fig. 2A, lanes 2 and 3), allowing quantitation of the products of endogenous and inserted genes in a single experiment. Rat $M L C 3_{\mathrm{f}} \mathrm{mRNA}$ accumulated to high levels in both $\mathrm{C}_{2} \mathrm{C}_{12}$ and $\mathrm{BC}_{3} \mathrm{H} 1$ transformants after differentiation (Fig. $2 \mathrm{~A})$. The presence of both rat and mouse myosin light-chain mRNAs in undifferentiated $\mathrm{C}_{2} \mathrm{C}_{12} / 19.7$ and $\mathrm{C}_{2} \mathrm{C}_{12} / 19.7 \mathrm{~B}$ cells (lanes 5 and 7) was probably due to the fact that there was a low level of spontaneous differentiation in $\mathrm{C}_{2} \mathrm{C}_{12}$ cells, even under the conditions used to maintain cells in the undifferentiated state. This did not occur in $\mathrm{BC}_{3} \mathrm{H} 1$ cells (lanes 9 and 11). When the mouse myosin light-chain band was used as an 

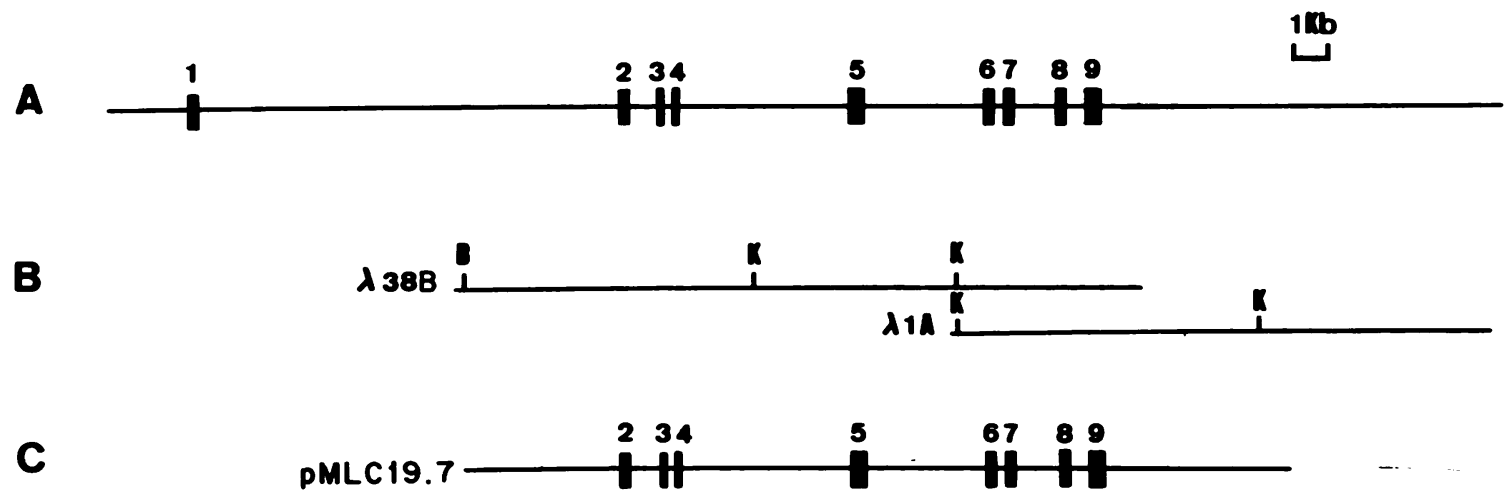

FIG. 1. Map of the rat $\mathrm{MLCl}_{\mathrm{f}} / 3_{\mathrm{f}}$ gene showing the arrangement of the exons (A, black bars), the location of two $\lambda$ Charon $4 \mathrm{a}$ clones, $\lambda 38 \mathrm{~B}$ and $\lambda 1 \mathrm{~A}$, used in the construction of pMLC19.7 (B), and the fragment of the gene present in pMLC19.7 (C). All maps are drawn to the same scale and are in proper alignment. B, BamHI; K, KpnI.

internal control for the amount of RNA loaded per lane, it was clear that in $\mathrm{C}_{2} \mathrm{C}_{12}$ cells, transformation with a linear or circular plasmid resulted in equivalent amounts of rat $M L C 3_{\mathrm{f}}$ mRNA (lanes 6 and 8), despite the fivefold difference in gene copy number, while in $\mathrm{BC}_{3} \mathrm{H} 1$ cells, there was less rat $\mathrm{MLC}_{\mathrm{f}}$ mRNA in cells transformed with the linearized plasmid than in those transformed with the circular plasmid (lanes 10 and 12). Whether this effect in $\mathrm{BC}_{3} \mathrm{H} 1$ cells was a reflection of the lower copy number in those cells transformed with the linearized plasmid is unknown.

Rat MLC3 $\mathrm{f}_{\mathrm{f}}$ mRA expression was also developmentally regulated in transiently transformed $\mathrm{C}_{2} \mathrm{C}_{12}$ cells (unpublished data). In this case, however, the level of expression of the rat MLC $_{\mathrm{f}}$ mRNA was considerably lower than that in stably transformed cells.

The nuclease $S 1$ probe used in the experiments shown in Fig. 2 begins in exon 5 and ends in exon 9. RNA from the transformed cells resulted in a nuclease S1-protected product that was the same size as that obtained with RNA from native rat skeletal muscle (Fig. 2A), indicating that the splicing of exons 5 to 6,6 to 7,7 to 8 , and 8 to 9 was accurate in the transformants.

$M L C 3_{f}$ mRNA is generated in vivo by the splicing together of exon 2 to exon 3 and of exon 3 to exon 5 (Fig. 2B). We wished to know whether this same pattern of splicing occurred after gene transfer of the truncated gene. Furthermore, we wished to test whether the formally acceptable splicing pattern 2-3-4-5, as well as the expected normal 2-3-5 splicing pattern, occurred with the truncated gene. The fidelity of splicing across the exon 2-exon 3-exon 5 region was determined by using primer extension assays. A 91base-pair cDNA fragment from within exon 5 was used as the primer (Fig. 3B). The major product generated by using rat skeletal muscle RNA as the template was 192 bases in length (Fig. 3A, lane 1), while the major product generated by usi mouse RNA was 188 bases in length (lane 2). This difference in length was due to a 4-base sequence that is presen in exon 2 of the rat gene but absent in that of the mouse gene $(1,9)$. In addition to the expected mouse product of 188 bases, RNA from differentiated $\mathrm{C}_{2} \mathrm{C}_{12} / 19.7$ cells (Fig. $3 \mathrm{~A}$, lane 3) yielded a band identical in size to that obtained with rat skeletal muscle RNA. These data indicated that exons 2 to 3 and 3 to 5 were accurately spliced together in the transformants.

A second product, 197 bases long, which was produced with rat skeletal muscle RNA as the template (Fig. 3A, lane 1) was not detected in the transformants (lane 3 ). It is

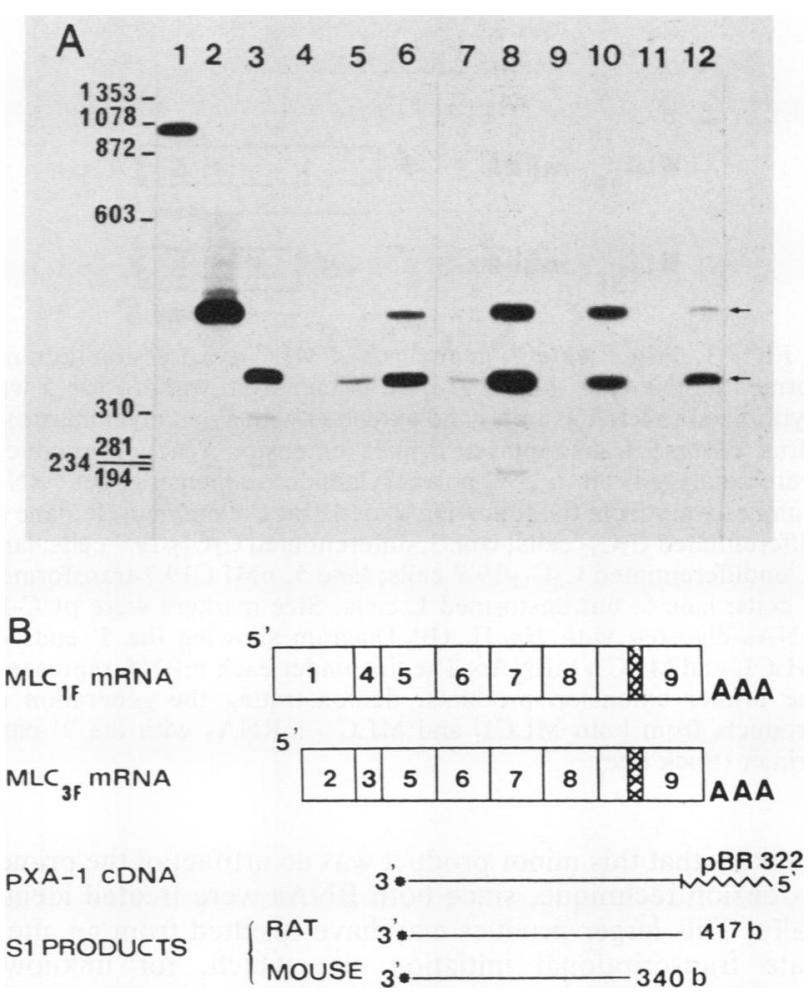

FIG. 2. Nuclease $\mathrm{S} 1$ analysis of rat $\mathrm{MLC}_{\mathrm{f}} \mathrm{mRNA}$ in transformed mouse cells. (A) Comparison of expression of rat $M L C 3_{f}$ mRNA in uninduced and induced transformants. Lane 1, Undigested probe. Lanes 2 to 12 , Nuclease S1 analysis of mRNAs from the following sources: 2 , rat skeletal muscle; 3 , differentiated mouse $\mathrm{C}_{2} \mathrm{C}_{12}$ cells; 4 , no RNA; 5 , undifferentiated $\mathrm{C}_{2} \mathrm{C}_{12} / 19.7 ; 6$, differentiated $\mathrm{C}_{2} \mathrm{C}_{12} / 19.7 ; 7$, undifferentiated $\mathrm{C}_{2} \mathrm{C}_{12} / 19.7 \mathrm{~B} ; 8$, differentiated $\mathrm{C}_{2} \mathrm{C}_{12} / 19.7 \mathrm{~B} ; 9$, undifferentiated $\mathrm{BC}_{3} \mathrm{H} 1 / 19.7$; 10 , differentiated $\mathrm{BC}_{3} \mathrm{H1} / 19.7 ; 11$, undifferentiated $\mathrm{BC}_{3} \mathrm{H1} / 19.7 \mathrm{~B}$; and 12 , differentiated $\mathrm{BC}_{3} \mathrm{H} 1 / 19.7 \mathrm{~B}$. Size markers were $\phi X 174$ replicativeform DNAs digested with HaeIII. (B) Diagrammatic representation of products expected from nuclease $\mathrm{S} 1$ analysis of rat and mouse $\mathrm{MLCl}_{\mathrm{f}}$ and $\mathrm{MLC}_{\mathrm{f}}$ mRNAs. The cross-hatched region in exon 9 corresponds to an 8-base sequence present in the rat and absent in the mouse. Thus, both rat $\mathrm{MLC1}_{\mathrm{f}}$ and $\mathrm{MLC}_{\mathrm{f}}$ mRNAs yielded a 417-base (b) product (upper arrow in panel A), while mouse mRNA was nicked at the site of these 8 bases, resulting in a 340-base (b) fragment (lower arrow in panel A). Asterisks indicate position of radioactive label. 


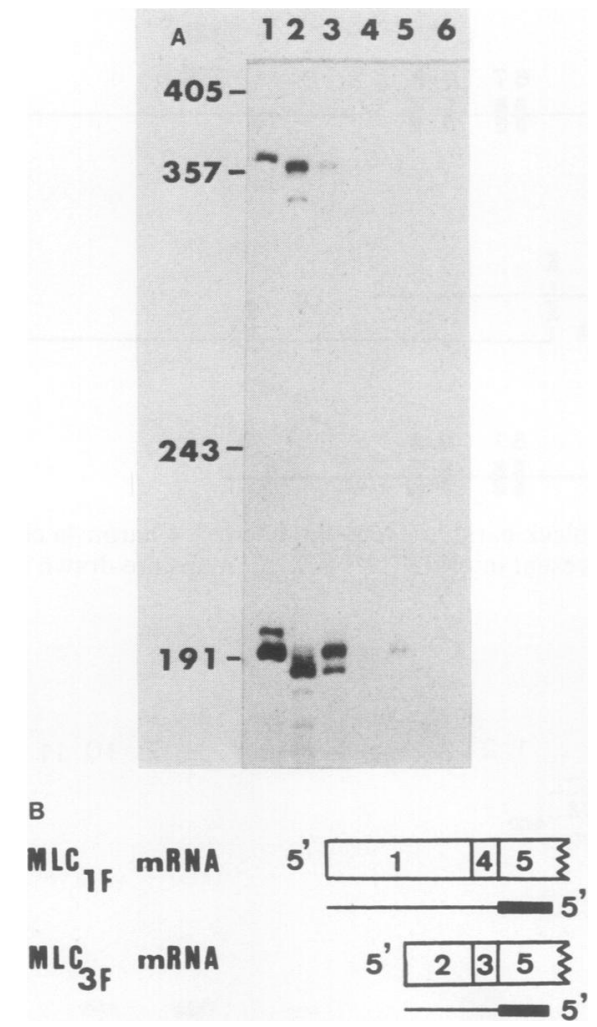

FIG. 3. Primer extension analysis of $\mathrm{MLC}_{\mathrm{f}}$ expression in transformed mouse cells. (A) A 91-base primer from within exon 5 was hybridized to RNA samples and extended with avian myeloblastosis virus reverse transcriptase. Primer extension reaction products were analyzed on a $5 \%$ polyacrylamide sequencing gel. RNA samples were from the following: lane 1 , rat skeletal muscle; lane 2, differentiated $\mathrm{C}_{2} \mathrm{C}_{12}$ cells; lane 3 , differentiated $\mathrm{C}_{2} \mathrm{C}_{12} / 19.7$ cells; lane 4 , undifferentiated $\mathrm{C}_{2} \mathrm{C}_{12} / 19.7$ cells; lane 5, pMLC19.7-transformed L cells; lane 6, untransformed L cells. Size markers were pUC-19 DNAs digested with HpaII. (B) Diagram showing the $5^{\prime}$ ends of $\mathrm{MLCl}_{\mathrm{f}}$ and $\mathrm{MLC}_{\mathrm{f}} \mathrm{mRNAs}$. The line under each mRNA represents the primer extension products, demonstrating the generation of products from both $\mathrm{MLC1}_{\mathrm{f}}$ and $\mathrm{MLC}_{\mathrm{f}}$ mRNAs with the 91-base primer (thick line).

unlikely that this minor product was an artifact of the primer extension technique, since both RNAs were treated identically. This larger product may have resulted from an alternate transcriptional initiation site which, for unknown reasons, was not used by the $\mathrm{C}_{2} \mathrm{C}_{12}$ cell transcriptional apparatus. Alternatively, there may have been sequences far upstream of the $\mathrm{MLC}_{\mathrm{f}}$ promoter but not present in pMLC19.7 which were required for the function of this second initiation site. Interestingly, the sequences at the beginning of the larger and smaller transcripts are

\section{ACTCCACTCAGGG (large) ACTCAGGG (small)}

both of which begin with ACTC (8). The bands in Fig. 3A at about 360 bases were the result of primer extension of rat and mouse $\mathrm{MLC1}_{\mathrm{f}} \mathrm{mRNAs}$, to which the 91-base primer was also homologous.

Although we have demonstrated accurate splicing in the pattern $2-3-5$ in the transformants, it is conceivable that incorrect splicing in the pattern 2-3-4-5 may occur, since the transfected gene is both truncated and outside of its normal

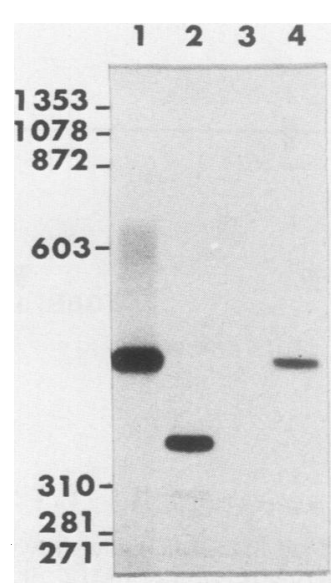

FIG. 4. Nuclease $S 1$ analysis of the expression of rat $\mathrm{MLC}_{\mathrm{f}}$ in $\mathrm{L}$ cells. The probe used was the same as that used in Fig. 2. RNA samples were from the following: lane 1, rat skeletal muscle; lane 2, differentiated $\mathrm{C}_{2} \mathrm{C}_{12}$ cells; lane 3 , untransformed $\mathrm{L}$ cells; lane 4 , pMLC19.7-transformed $L$ cells.

genetic context. If 2-3-4-5 splicing occurred, the products that would result from the use of the 91-base exon 5 primer in a primer extension reaction would be a major band 216 bases long and a minor band 221 bases long. There was no detectable product of this size in primary rat tissue or in $\mathrm{C}_{2} \mathrm{C}_{12} / 19.7$ cells (Fig. 3A, lanes 1 and 3 ).

These results, taken together, demonstrated that after gene transfer the truncated gene showed both regulated expression and the correct in vivo alternative splicing pattern in the myogenic $\mathrm{C}_{2} \mathrm{C}_{12}$ and $\mathrm{BC}_{3} \mathrm{H} 1$ cell lines. Thus, our work shows that there are promoter elements within or slightly upstream of the $\mathrm{MLC}_{\mathrm{f}}$ gene which can function independently of the promoter elements of the $\mathrm{MLCl}_{\mathrm{f}}$ gene. Our results are consistent with those of previous studies showing that there are sequences just preceding exon 2 which function as promoter elements for correctly initiated transcripts in vitro (13). Since both mRNAs are induced during differentiation, the promoters for $\mathrm{MLCl}_{\mathrm{f}}$ and $\mathrm{MLC}_{\mathrm{f}}$ mRNAs must either be regulated separately by loci associated with each promoter or regulated together by sequences contained within the truncated gene.

Mouse L cells were transformed with pMLC19.7 and assayed for the expression of rat $M L C 3_{\mathrm{f}}$. Rat $\mathrm{MLC}_{\mathrm{f}}$ mRNA was produced and accurately processed in $\mathrm{L}$ cells (Fig. 3A, lane 5, and Fig. 4, lane 4). As in the $C_{2} C_{12}$ transformants, there was no evidence of exon 4 being spliced into the rat $\mathrm{MLC}_{\mathrm{f}}$ mRNA (Fig. 3A, lane 5). While the expression of MLC $_{\mathrm{f}}$ mRNA in mouse $\mathrm{L}$ cells was unexpected, it is not without precedent. There are numerous examples of inappropriate expression of transfected genes in L cells. $\alpha$-Actin (11), T-cell differentiation antigens (2), human growth hormone (10), and even chicken ovalbumin (4) genes are inappropriately expressed in $\mathrm{L}$ cells. The reasons for the frequent occurrence of inappropriate expression in the fibroblast L-cell line are not known. More importantly, our observation that the correct 2-3-5 splicing pattern occurs in $\mathrm{L}$ cells supports the view that the signals for correct splicing of this complex transcript are intrinsic to the RNA itself and are not related to its tissue of origin.

We acknowledge the expert technical assistance of Marie Krempin. We also thank Carlos Gitler of the Department of Mem- 
brane Research, Weizmann Institute of Science, in whose laboratory part of this work was done.

This research was supported by a grant from the Muscular Dystrophy Association to N.D. L.I.G. was supported by National Research Service Award 5F32GM09157 from the National Institutes of Health.

\section{LITERATURE CITED}

1. Garfinkel, L. I., M. Periasamy, and B. Nadal-Ginard. 1982. Cloning and characterization of CDNA sequences corresponding to myosin light chains 1,2 , and 3, troponin-C, troponin-T, $\alpha$-tropomyosin, and $\alpha$-actin. J. Biol. Chem. 257:11078-11086.

2. Kavathas, P., and L. A. Herzenberg. 1983. Stable transformation of mouse $\mathrm{L}$ cells for human membrane $\mathrm{T}$-cell differentiation antigens, HLA and $\beta_{2}$-microglobulin: selection by fluorescenceactivated cell sorting. Proc. Natl. Acad. Sci. USA 80:524 528.

3. Kim, S. K., and B. J. Wold. 1985. Stable reduction of thymidine kinase activity in cells expressing levels of anti-sense RNA. Cell 42:129-138.

4. Lai, E. C., S. L. C. Woo, M. E. Berdelon-Riser, T. H. Fraser, and B. W. O'Malley. 1980. Ovalbumin is synthesized in mouse cells transformed with the natural chicken ovalbumin gene. Proc. Natl. Acad. Sci. USA 77:244-248.

5. Levis, R., T. Hazelrigg, and G. M. Rubin. 1986. Effects of genomic position on the expression of transduced copies of the white gene of Drosophila. Science 229:558-561.

6. Miller, A. D., E. S. Ong, M. G. Rosenfeld, I. M. Verma, and R. M. Evans. 1984. Infectious and selectable retrovirus containing an inducible rat growth hormone minigene. Science 225: 993-998.

7. Nabeshima, Y., Y. Fujii-Kuriyama, M. Muramatsu, and K. Ogata. 1984. Alternative transcription and two modes of splicing result in two myosin light chains from one gene. Nature (London) 308:333-338.

8. Periasamy, M., E. E. Strehler, L. I. Garfinkel, R. M. Gubits, N. Ruiz-Opazo, and B. Nadal-Ginard. 1984. Fast skeletal muscle myosin light chains 1 and 3 are produced from a single gene by a combined process of differential RNA transcription and splicing. J. Biol. Chem. 259:13595-13604.

9. Robert, B., P. Daubas, M.-A. Akimenko, A. Cohen, I. Garner, J.-L. Guenet, and M. Buckingham. 1984. A single locus in the mouse encodes both myosin light chains 1 and 3 , a second locus corresponds to a related pseudogene. Cell 39:129-140.

10. Robins, D. M., I. Paek, P. H. Seeburg, and R. Axel. 1982. Regulated expression of human growth hormone genes in mouse cells. Cell 29:623-631.

11. Seiler-Tuyns, A., J. D. Eldridge, and B. M. Paterson. 1984 Expression and regulation of chicken actin genes introduced into mouse myogenic and nonmyogenic cells. Proc. Natl. Acad. Sci. USA 81:2980-2984.

12. Shubert, D. A., J. Harris, C. E. Devine, and S. Heinemann. 1974 Characterization of a unique muscle cell line. J. Cell Biol. 61 398-413.

13. Strehler, E. E., M. Periasamy, M.-A. Strehler-Page, and B. Nadal-Ginard. 1985. Myosin light-chain 1 and 3 gene has two structurally distinct and differentially regulated promoters evolving at different rates. Mol. Cell. Biol. 5:3168-3182.

14. Wakimoto, B. T., L. J. Kalfayan, and A. L. Spradling. 1986. Developmentally regulated expression of Drosophila chorion genes introduced at diverse chromosomal positions. J. Mol Biol. 187:33-45.

15. Wigler, M., A. Pellicer, S. Silverstein, and R. Axel. 1978 Biochemical transfer of single-copy eucaryotic genes using total cellular DNA as donor. Cell 14:725-731.

16. Yaffe, D., and O. Saxel. 1977. Serial passaging and differentiation of myogenic cells isolated from dystrophic mouse muscle. Nature (London) 270:725-727. 